\title{
Penguatan Usaha Kecil Berbasis Godong Simbukan dalam Meningkatkan Ekonomi Masyarakat Kabupaten Lumajang
}

\author{
Ninik Lukiana*1, Riza Bahtiar Sulistyan² \\ 1,2 Program Studi Manajemen, STIE Widya Gama Lumajang \\ *e-mail: ibundaninik@gmail.com ${ }^{1}$, rizabahtiars@gmail.com²
}

\begin{abstract}
Small businesses in Indonesia have experienced a better development. However, in the era of the Covid-19 pandemic, it experienced a decline and affected the economic condition of the community. No exception to small businesses with innovations from godong simbukan located in Lumajang district. This business has also experienced a decline, even though it was just established. This needs to be supported by strengthening in the form of mentoring and training. The most urgent assistance activity is in the form of assistance to conduct a business feasibility analysis. Meanwhile, training is in the form of preparing financial reports according to standards and planning for the coming period. The result of mentoring is an increase in the ability of partners in analyzing business feasibility, as well as being able to carry out the analysis independently if they want to increase their business. The training resulted in the ability to compile financial reports and enter them into their posts
\end{abstract}

Keywords: Small Business, Mentoring, Training, Capability

\begin{abstract}
Abstrak
Usaha kecil di Indonesia telah mengalami perkembangan kearah yang lebih baik. Namun di era pandemi covid-19 mengalami kemerosotan dan berpengaruh pada kondisi perekonomian masyarakat. Tidak terkecuali usaha kecil dengan inovasi dari godong simbukan yang terletak di Kabupaten Lumajang. Usaha ini juga mengalami kemerosotan, padahal baru berdiri di pertengahan tahun 2019. Hal ini perlu ditunjang dengan penguatan baik berupa pendampingan maupun pelatihan. Kegiatan pendampingan yang paling mendesak adalah berupa pendampingan untuk melakukan analisis kelayakan usaha. Sedangkan pelatihan berupa penyusunan laporan keuangan yang sesuai dengan standar dan perencanaan untuk periode yang akan datang. Hasil dari pendampingan adalah terjadinya peningkatan kemampuan dari mitra dalam menganalisis kelayakan usaha, serta dapat melakukan analisis secara mandiri apabila ingin meningkatkan usahanya. Pelatihan menghasilkan kemampuan menyusun laporan keuangan dan memasukkan kedalam pos neraca dan laporan laba rugi.
\end{abstract}

Kata kunci: Usaha Kecil, Pendampingan, Pelatihan, Kemampuan

\section{PENDAHULUAN}

Usaha kecil di Indonesia sebelumnya telah menunjukkan perkembangan kearah yang lebih baik (Nursalim, Sampeallo, Wahid, \& Meok, 2019). Namun usaha kecil dan menengah saat ini telah berada titik kritis atau terdapat guncangan ekonomi yang disebabkan oleh pandemi covid-19. Adanya lockdown di beberapa daerah telah menghentikan aktivitas ekonomi secara mendadak, sehingga menurunkan permintaan dan mengganggu sistem distribusi. Dari hasil survei, lebih dari $50 \%$ usaha kecil dan menengah mengalami gulung tikar. Tentu hal ini sangat berpengaruh pada kondisi perekonomian di Indonesia (Thaha, 2020). Oleh sebab itu dalam menghadapi situasi yang tidak menentu ini akibat pandemi covid-19, para pelaku usaha harus memiliki konsep bisnis yang matang dan produk yang mampu bersaing di masyarakat. Apalagi dalam bentuk makanan karena adanya pembatasan aktivitas masyarakat (Fadrul, Rahman, Sudarno, \& Yusrizal, 2020).

UKM yang ada di Indonesia mengalami satu permasalahan berupa kurangnya kemampuan manajerial dalam berwirausaha (Wirda, Herizon, \& Putra, 2020). Usaha kecil yang ada di masyarakat merupakan penopang utama perekonomian masyarakat Indonesia (Fadilah, 2019). Keberhasilan yang diraih oleh usaha tersebut juga memiliki kelemahan yang harus diselesaikan seperti kurangnya modal berupa jumlah atau sumber dari modal itu sendiri, kemampuan manajerial, serta kurangnya keterampilan pengoperasian dalam mengorganisir 
dan pemasaran yang terbatas (Suci, 2017). Hal penting dalam menunjang keberhasilan adalah dalam penyusunan laporan keuangan yang sistematis dan terencana dengan baik. Di Kabupaten Lumajang masih ditemui permasalahan terkait dengan lemahnya penyusunan laporan keuangan (Fadilah, 2019). Tidak hanya itu, studi tentang penyusunan laporan keuangan di beberapa tahun terakhir di Kabupaten Lumajang sudah menjadi perhatian khusus (Lestari, Susbiyani, \& Syahfudrin, 2018; Setyobakti, 2018), serta berbagai pelatihan khususnya di era pandemi covid19 yang lebih diarahkan pada kegiatan secara daring atau online (Sulistyan, 2020; Sulistyan \& Ermawati, 2020).

Menjalankan sebuah usaha kecil perlu dilakukan tidak hanya secara offline tetapi juga online seperti pembuatan website atau melalui aplikasi lain (Sulistyan, 2017). Disisi lain yang terjadi di Kabupaten Lumajang yaitu adanya keraguan atau ketakutan akan kerugian dalam menjalankan usaha (Wiranata \& Jayatri, 2020). Usaha kecil atau usaha rumahan yang semakin ketat persaingannya apabila ditunjang dengan perencanaan yang kuat, maka akan dapat bertahan dalam jangka panjang. Strategi pemberdayaan masyarakat dalam pembentukan usaha kecil di Kabupaten Lumajang dapat dianalisis dari berbagai sektor dan dibutuhkan inovasi dalam pengembangan usaha (Sulistyan, Setyobakti, \& Darmawan, 2019). Adanya program pemberdayaan diharapkan akan memberikan manfaat baik jangka pendek maupun jangka panjang (Masnita, Khomsiyah, \& Triyowati, 2020).

Salah satu usaha masyarakat yang juga mengalami penurunan penjualan yaitu produk dari bahan dasar simbukan. Simbukan atau sembukan merupakan tumbuhan liar yang dapat dimanfaatkan sebagai obat tradisional pada bagian batang dan daun. Tumbuhan tersebut mengandung metabolit sekunder seperti flavonoid, alkoid, minyak atsiri, dan steroid (Ekawati, Suirta, \& Santi, 2017). Simbukan di Kabupaten Lumajang lebih sering dijumpai dalam bentuk botok. Namun seiring dengan perkembangan teknologi perlu adanya inovasi agar daun simbukan yang melimpah di Kabupaten Lumajang dapat dimanfaatkan dalam bentuk lain dan semakin diminati masyarakat.

Survei yang dilakukan Agustus 2020 terhadap pelaku usaha kecil olahan daun simbukan yaitu yang dikelola oleh masyarakat Desa Tempeh Kidul, Kecamatan Tempeh, Kabupaten Lumajang. Usaha ini masih tergolong baru, karena baru beberapa tahun berdiri dan terdapat beberapa inovasi produk yang berasal dari daun simbukan tersebut, seperti botok simbukan, godong simbukan crispy, krupuk simbukan, stik simbukan, dan masih akan dikembangkan lagi dalam bentuk beberapa produk. Segmentasi produk olahan ini yaitu di segala usia, mulai dari anak-anak lebih dari 5 tahun sampai usia dewasa. Selain itu dengan harga yang murah juga disesuaikan dengan pendapatan masyarakat yang ada di Kabupaten Lumajang.

Usaha kecil berbahan dasar gosong simbukan ini masih belum terkelola dengan baik khususnya dibidang perencanaan dan penyusunan laporan keuangan, sehingga antara modal yang dikeluarkan dengan pendapatan yang diterima tidak dapat diketahui secara detail. Analisis usaha ini juga belum dilakukan dari segi kelayakan usaha, sehingga perhitungan dalam jangka panjang seperti adanya penyusutan atau faktor lainnya belum dapat diketahui.

\section{METODE}

Metode pelaksanaan pengabdian kepada masyarakat berupa pelatihan yang terdiri dari 3 tahapan yaitu persiapan, pelaksanaan, dan evaluasi (Sulistyan et al., 2019). Masing-masing tahapan dijelaskan sebagai berikut:

a. Tahap Persiapan

Tahap persiapan dimulai dari analisis lebih mendalam terkait permasalahan mitra yang meliputi analisis kelayakan usaha dan kemampuan mitra dalam menyusun laporan keuangan. Hasil analisis tersebut akan dicari solusi bersama-sama dengan mitra dan penentuan jadwal pelaksanaan kegiatan untuk menyelesaikan masalah tersebut. 


\section{b. Tahap Pelaksanaan}

Tahap pelaksanaan berupa dua kegiatan, yaitu mulai menganalisis dari segi kelayakan usaha dan pelatihan penyusunan laporan keuangan. Pendampingan kelayakan usaha dilakukan dengan metode analisis capital budgeting dan beberapa aspek penting dalam analisis tersebut. Pelatihan penyusunan laporan keuangan diawali dengan pengenalan pospos di laporan keuangan dan dilanjutkan teknik penyusunan laporan keuangannya.

\section{c. Tahap Evaluasi}

Tahap evaluasi dilakukan dengan memberikan kasus dalam analisis kelayakan usaha apabila dimungkinkan untuk pengembangan produk baru. Evaluasi dalam penyusunan laporan keuangan dilakukan dengan kemampuan menyusun secara mandiri dengan memasukkan pos-pos laporan keuangan.

Tingkat keberhasilan kegiatan pengabdian kepada masyarakat ini dilakukan dengan memberikan penilaian dari peserta berupa pemahaman analisis kelayakan usaha dan penyusunan laporan keuangan. Kriteria keberhasilan dinilai tinggi apabila mencapai nilai 76100, sedang dengan nilai 51-70, dan kurang dengan nilai 0-50. Penilaian ini dilihat dari skor total sehingga tingkat keberhasilan dari kegiatan dapat dideskripsikan. Penilaian dilakukan dari aspek pengetahuan, praktek, dan pemahaman. Adapun masing-masing penilaian tersebut dijabarkan pada tabel sebagai berikut:

Tabel 1. Penilaian Tingkat Keberhasilan Pengabdian Kepada Masyarakat

\begin{tabular}{|c|c|c|c|}
\hline No. & Uraian Penilaian & Output & Skor \\
\hline \multirow[t]{7}{*}{1} & Pengetahuan & & \\
\hline & $\begin{array}{l}\text { Analisis Kelayakan Usaha } \\
\text { - Payback Period }\end{array}$ & $\begin{array}{l}\text { Mampu menganalisis kelayakan } \\
\text { usaha di berbagai aspek }\end{array}$ & 5 \\
\hline & Net Present Value & & \\
\hline & - IRR & & \\
\hline & Laporan Keuangan & Mampu menyusun laporan & 5 \\
\hline & - Estimasi Biaya & keuangan sederhana yang dilakukan & \\
\hline & - Laporan Laba Rugi & pada usahanya & \\
\hline \multirow[t]{7}{*}{2} & Praktek & & \\
\hline & Analisis kelayakan usaha dengan & Mampu secara mandiri kelayakan & 30 \\
\hline & adanya produk baru & $\begin{array}{l}\text { usaha apabila ada inovasi produk } \\
\text { baru }\end{array}$ & \\
\hline & Penyusunan laporan keuangan dengan & Mampu menyusun laporan & 30 \\
\hline & memasukkan pada pos-posnya & keuangan dengan input yang & \\
\hline & & beragam kedalam pos-pos laporan & \\
\hline & & keuangan & \\
\hline \multirow[t]{5}{*}{3} & Pemahaman & & \\
\hline & Interpretasi atas hasil analisis & Mampu menginterpretasi hasil & 15 \\
\hline & kelayakan usahanya & analisis kelayakan usahanya & \\
\hline & Menganalisis laporan keuangan yang & Mampu menganalisis laporan & 15 \\
\hline & $\begin{array}{l}\text { telah disusun dan merencanakan untuk } \\
\text { periode yang akan datang }\end{array}$ & $\begin{array}{l}\text { keuangan serta rencana untuk } \\
\text { periode yang akan datang }\end{array}$ & \\
\hline \multicolumn{2}{|c|}{ Jumlah Total } & & 100 \\
\hline
\end{tabular}




\section{HASIL DAN PEMBAHASAN}

\subsection{Hasil Kegiatan}

Kegiatan pengabdian kepada masyarakat ini dilaksanakan sesuai dengan tahapan yang sudah direncankan, mulai dari tahap persiapan, tahap pelaksanaan, dan tahap evaluasi. Hasil pelaksanaan kegiatan dijabarkan sebagai berikut:

\section{a. Tahap Persiapan}

Tahap ini dimulai telah dilaksanakan dengan melakukan survei awal. Didapatkan permasalahan mitra dari segi kelayakan usaha, yaitu adanya keraguan apabila melakukan inovasi produk baru. Dalam hal ini diperlukan analisis kelayakan usaha seperti yang telah disusun dalam rencana awal yaitu menggunakan pendekatan capital budgeting.

Tahap persiapan pada aspek penyusunan laporan keuangan yang menjadi permasalahan adalah minimnya pengetahuan mengenai laporan keuangan, sehingga dalam penyusunan laporan keuangan selama ini masih menggunakan sistem tradisional. Selama ini pelaporan keuangan hanya mencatat modal yang dikeluarkan dan hasil yang diperoleh, belum sampai pada berapa tingkat penyusutannya, biaya lain-lain, perhitungan titik impas, dan laba bersih yang diterima.

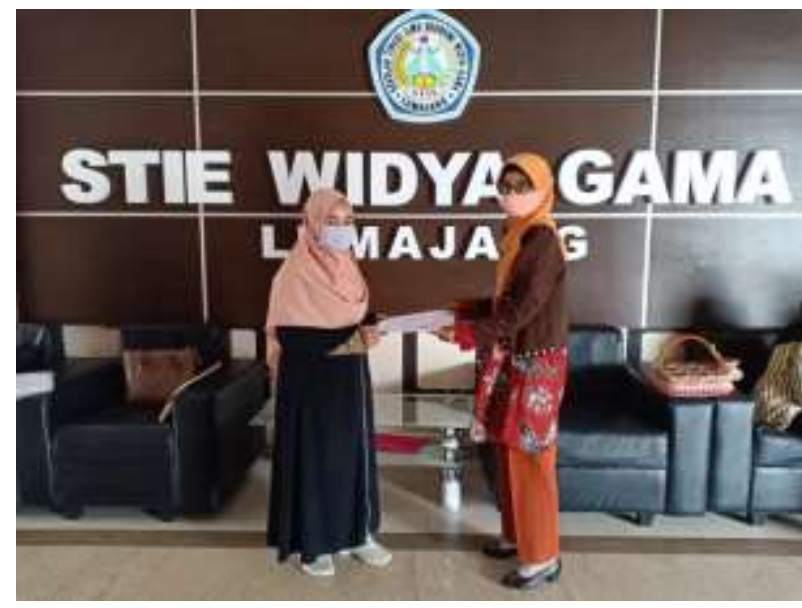

Gambar 1. Persiapan dan Kerjasama Pengabdian

\section{b. Tahap Pelaksanaan}

Pelaksanaan kegiatan ini dimulai dari melakukan identifikasi biaya-biaya yang dikeluarkan dalam memproduksi produk. Identifikasi biaya terdiri dari perlengkapan dan biaya habis pakai. Biaya untuk perlengkapan mencapai Rp. 2.805.000,- dan biaya habis pakai mencapai Rp. 263.000,-. Adapun hasil perhitungan secara detail disajikan pada lampiran.

Pendampingan ini dimulai dari pengenalan beberapa istilah-istilah yang digunakan dalam perhitungan menggunakan analisis capital budgeting. Perhitungan analisis capital budgeting telah diperoleh payback period atau modal akan kembali dalam waktu 1 tahun 12 hari. Net present value menunjukkan bahwa pada diskon faktor $5 \%$ dan $10 \%$, sama-sama bernilai NPV lebih dari 0 . Hal ini berarti investasi yang dilakukan akan memberikan manfaat bagi usahanya dan proyek bias dilakukan. Dilihat dari IRR (Internal Rate of Return) menunjukkan nilai sebesar 5,6\%. Hal ini berarti suku bunga yang akan menyamakan jumlah nilai sekarang dari penerimaan yang diharapkan diterima dengan jumlah nilai sekarang dari pengeluaran untuk investasi sebesar $5,6 \%$.

Pelaksanaan kegiatan pelatihan penyusunan laporan keuangan usaha dilakukan dengan memberikan pemahaman pada pos-pos yang ada di laporan keuangan (neraca dan laba rugi). Pos-pos tersebut antara lain biaya-biaya untuk pengeluaran, break event point, dan proyeksi keuangan. Pemberian pemahaman ini untuk mempermudah komunikasi dalam pelatihan penyusunan laporan keuangan. Hasil pelatihan ini berupa laporan keuangan laba rugi dan 
analisis BEP (Break Event Point). Dari laporan keuangan laba rugi diperoleh pendapatan bersih pertahun sebesar Rp. 15.364.816,-. BEP dalam unit sebesar 1.229 produk dan BEP dalam rupiah sebesar Rp. 9.350.000,-. Analisis harga jual per unit diperoleh sebesar Rp. 8.000,-.

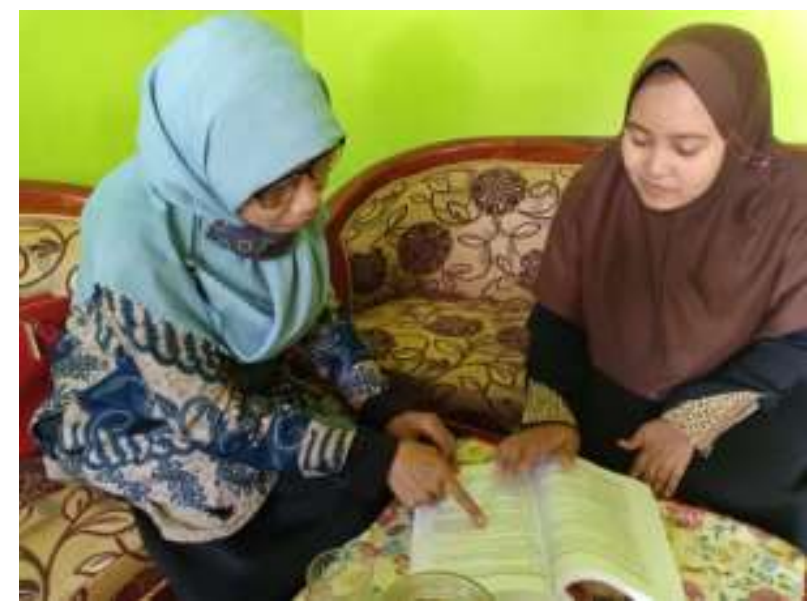

Gambar 2. Pelatihan Penyusunan Laporan Keuangan

c. Tahap Evaluasi

Evaluasi dilakukan untuk menilai tingkat pemahaman mitra dari kegiatan yang telah dilakukan. Evaluasi secara detail dijabarkan pada tabel sebagai berikut:

Tabel 2. Hasil Evaluasi Kegiatan

\begin{tabular}{|c|c|c|}
\hline & Uraian Penilaian & Skor \\
\hline \multirow{8}{*}{$\frac{\text { No. }}{1}$} & Pengetahuan & \\
\hline & Analisis Kelayakan Usaha & 5 \\
\hline & - Payback Period & \\
\hline & - Net Present Value & \\
\hline & - IRR & \\
\hline & Laporan Keuangan & 5 \\
\hline & - Estimasi Biaya & \\
\hline & - Laporan Laba Rugi & \\
\hline \multirow[t]{3}{*}{2} & Praktek & \\
\hline & Analisis kelayakan usaha dengan adanya produk baru & 20 \\
\hline & Penyusunan laporan keuangan dengan memasukkan pada pos-posnya & 20 \\
\hline \multirow[t]{3}{*}{3} & Pemahaman & \\
\hline & Interpretasi atas hasil analisis kelayakan usahanya & 10 \\
\hline & $\begin{array}{l}\text { Menganalisis laporan keuangan yang telah disusun dan } \\
\text { merencanakan untuk periode yang akan datang }\end{array}$ & 10 \\
\hline \multicolumn{2}{|c|}{ Jumlah Total } & 70 \\
\hline
\end{tabular}

Hasil evaluasi menunjukkan bahwa nilai skor total 70 yang berarti bahwa kegiatan dinilai sedang. Hasil ini menunjukkan bawah peserta kurang memahami atas pratek yang telah dilakukan. Selain itu tingkat pemahaman atas interpretasi hasil juga dinilai masih kurang, sehingga masih diperlukan pemahaman atas interpretasi yang dilakukan.

\subsection{Pembahasan}

Pelaksanaan kegiatan ini telah membawa dampak positif bagi mitra. Meskipun hasil evaluasi menunjukkan nilai sedang, namun seiring dengan tingkat kebiasaan mitra akan mampu menaikkan nilai dan mampu secara mandiri melakukan analisis kelayakan usaha dan menyusun laporan keuangan dengan benar. Analisis kelayakan usaha berupa payback period, net present 
value dan internal rate of return akan menjadi pertimbangan bagi pelaku usaha dalam melakukan inovasi produk baru yang berasal dari daun simbukan.

Analisis kelayakan usaha semacam ini khususnya di era pandemi covid-19 seperti ini sangat perlu dilakukan, dimana kelangsungan usaha akan berjangka panjang atau tidak. Dari hasil perhitungan payback period menunjukkan hasil 1 tahun 12 hari. Akan tetapi hasil ini dapat berubah sesuai dengan keadaan yang sedang terjadi saat ini. Dilihat dari hasil net present value memang lebih dari 0 dan layak untuk dilanjutkan dalam pengembangan usaha. Namun hasil ini juga dapat berubah seiring dengan tingkat suku bunga bank yang ditetapkan pemerintah. Nilai IRR sebesar $5,6 \%$ dan hasil ini dapat dibandingkan dengan nilai uang dimasa sekarang dengan yang diharapkan. Pendampingan kelayakan usaha ini memberikan wawasan mitra akan pentingnya perhitungan semacam ini dan interpretasinya dapat dijadikan dasar penentu usaha tersebut layak untuk dilanjutkan atau tidak.

Pelatihan penyusunan laporan keuangan kepada mitra juga menimbulkan dampak positif. Hal ini dapat dilihat dari meningkatnya pemahaman yang sebelumnya sama sekali belum mengenal pos-pos di laporan keuangan. Pelatihan ini berupa penyusunan proyeksi keuangan, laporan laba rugi, dan perhitungan BEP. Praktek sudah dapat dilakukan mandiri oleh mitra, namun masih belum maksimal dan memang baru pertama kali menyusun laporan keuangan sesuai dengan standar. Interpretasi laporan keuangan yang telah disusun dapat mempermudah mitra untuk melihat berapa produk minimal yang harus dijual dan berapa pendapatan minimal agar mengalami titik impas. Dapat diketahui pula laba bersih dari usaha yang telah dilakukan pada laporan keuangan tersebut.

\section{KESIMPULAN}

Pendampingan kelayakan usaha dan pelatihan penyusunan laporan keuangan telah memberikan dampak positif bagi mitra. Di era pandemi covid-19, analisis kelayakan usaha dan penyusunan laporan keuangan yang benar sangat diperlukan agar perencanaan pada periode yang akan datang tidak terjadi penyimpangan yang tinggi. Terjadi perbedaan antara sebelum kegiatan pendampingan dan pelatihan. Survei awal, mitra belum memahami cara melakukan analisis kelayakan usaha dan belum mampu menyusun laporan keuangan. Namun setelah kegiatan dilakukan terjadi peningkatan mulai dari pengetahuan, praktek langsung, dan pemahaman dari analisis kelayakan usaha dan penyusunan laporan keuangan.

\section{UCAPAN TERIMA KASIH}

Ucapan terima kasih kami sampaikan kepada STIE Widya Gama Lumajang atas dukungan financial dan memfasilitasi kegiatan pengabdian kepada masyarakat ini. Ucapan terima kasih juga kami sampaikan kepada pengelola jurnal Dinamisia: Jurnal Pengabdian Kepada Masyarakat yang telah memberikan kesempatan untuk mempublish artikel pengabdian kami.

\section{DAFTAR PUSTAKA}

Ekawati, M. A., Suirta, I. W., \& Santi, S. R. (2017). Isolasi dan Identifikasi Senyawa Flavonoid pada Daun Sembukan (Paederia Foetida L) Serta Uji Aktivitasnya sebagai Antioksidan. Jurnal Kimia, 11(1), 43-48. doi: 10.24843/JCHEM.2017.v11.i01.p07

Fadilah, N. (2019). Pengaruh Kualitas Sumber Daya Manusia dan Karakteristik Usaha terhadap Kualitas Laporan Keuangan UKM Kabupaten Lumajang. Journal of Economic, Bussines and Accounting (COSTING), 2(2), 263-271. doi: 10.31539/costing.v2i2.557

Fadrul, Rahman, S., Sudarno, \& Yusrizal. (2020). Program Pengembangan Usaha Produk Intelektual Kampus "Kantor Konsultan Bisnis, Akuntansi dan Pajak". Dinamisia : Jurnal Pengabdian Kepada Masyarakat, 4(3), 447-453. doi: 10.31849/dinamisia.v4i3.4738 
Lestari, S. R. D., Susbiyani, A., \& Syahfudrin, A. (2018). Analisis Penyusunan Laporan Operasional pada Badan Pengelola Keuangan dan Aset Daerah Kabupaten Lumajang. International Journal of Social Science and Business, 2(2), 224-230.

Masnita, Y., Khomsiyah, \& Triyowati, H. (2020). Peningkatan Daya Saing Usaha Mikro (UMi) Melalui Keuangan Inklusi. Dinamisia : Jurnal Pengabdian Kepada Masyarakat, 4(2), 255-262. doi: 10.31849 /dinamisia.v4i2.3964

Nursalim, Sampeallo, A. S., Wahid, A., \& Meok, N. J. (2019). Upaya Peningkatan Produksi Mebel Pada UMKM Kota Kupang Berbasis Teknologi Tepat Guna. Dinamisia : Jurnal Pengabdian Kepada Masyarakat, 3(2), 258-265.

Setyobakti, M. H. (2018). Peningkatan Kapasitas Pelaporan Keuangan Bumdesa Gesang Sejahtera Desa Gesang Kecamatan Tempeh Kabupaten Lumajang. Empowerment Society, 1(1), 1-8. doi: 10.30741/eps.v1i1.167

Suci, Y. R. (2017). Perkembangan UMKM (Usaha Mikro Kecil dan menengah) di Indonesia. Jurnal Ilmiah Cano Ekonomos, 6(1), 51-58.

Sulistyan, R. B. (2017). Website Management Training Tourism Village in Sumber Pakel Padang District Lumajang. International Journal of Society Development and Engagement, 1(1), 120128. doi: $10.29138 /$ scj.v1i2.587

Sulistyan, R. B. (2020). Lecturer E-learning Training: The Role of Social Exchange Theory. Empowerment Society, 3(2), 50-56. doi: 10.30741/eps.v3i2.589

Sulistyan, R. B., \& Ermawati, E. (2020). Explaining Cyberloafing Behavior: The Role of General Strain Theory. Wiga : Jurnal Penelitian Ilmu Ekonomi, 10(2), 148-156. doi: 10.30741/wiga.v10i2.596

Sulistyan, R. B., Setyobakti, M. H., \& Darmawan, K. (2019). Strategi Pemberdayaan Masyarakat melalui Program Pembentukan Destinasi Wisata dan Usaha Kecil. Empowerment Society, 2(2), 1-7. doi: 10.30741/eps.v2i2.457

Thaha, A. F. (2020). Dampak Covid-19 terhadap UMKM di Indonesia. Jurnal Brand, 2(1), 147-153.

Wiranata, R., \& Jayatri, F. (2020). Pemberdayaan Masyarakat dalam Meningkatkan Peluang Kewirausahaan melalui Pelatihan Pembuatan Pudding Art di Desa Wonosari Kecamatan Tekung Kabupaten Lumajang. ABDIMAS NUSANTARA: Jurnal Pengabdian Kepada Masyarakat, 2(1), 270-278.

Wirda, F., Herizon, \& Putra, T. J. (2020). Penguatan Daya Saing UKM Pada Usaha Makanan Khas Daerah Sumatera Barat. Dinamisia : Jurnal Pengabdian Kepada Masyarakat, 4(4), 579-587. doi: $10.31849 /$ dinamisia.v4i3.4165 